\title{
PENGELOLAAN ALOKASI DANA DESA \\ (STUDI PADA DESA ALASMALANG KECAMATAN PANARUKAN KABUPATEN SITUBONDO)
}

\author{
SIGIT SUSTYO RAHARJO* \\ PUJI WAHONO \\ EDY WAHYUDI \\ Program Studi Magister Ilmu Administrasi \\ Fakultas Ilmu Sosial dan Ilmu Politik \\ Universitas Jember \\ *Email: sigitnamaku27@gmail.com
}

\begin{abstract}
ABSTRAK
Keterbatasan keuangan yang dimiliki desa menyebabkan ketimpangan pembangunan antara desa dengan kota. Diperlukan keberpihakan pemerintah pusat dan daerah dalam mendukung ketersediaaan anggaran bagi desa untuk melaksanakan tata kelola pemerintahan dan pembangunan. Alokasi Dana Desa (ADD) merupakan salah satu cara untuk mempercepat pembangunan di desa. Sejak tahun 2015, terjadi peningkatan yang signifikan atas penerimaan ADD karena Kabupaten wajib menganggarkan minimal $10 \%$ dari APBD untuk alokasi dana desanya sesuai amanah Undang-undang Nomor 6 Tahun 2014. Peningkatan ADD tersebut merupakan berkah dan tantangan bagi desa untuk bisa mengelola sesuai dengan prinsip-prinsip tata kelola pemerintahan yang baik (good governance). Karena desa saat ini masih dihadapkan pada keterbatasan kualitas sumber daya aparatur yang rendah, rendahnya kemampuan perencanaan, dan sarana prasarana lam pengelolaan ADD.
\end{abstract}

Kata Kunci: Pengelolaan, Alokasi Dana Desa 


\section{PENDAHULUAN}

Pembangunan desa memiliki arti dan peranan yang sangat strategis bagi pembangunan daerah dan nasional. Hal tersebut dikarenakan bahwa pembangunan desa akan menjadikan pemerataan pembangunan dan hasil-hasilnya yang akan berdampak langsung kepada masyarakat secara luas yang bermukim di perdesaan serta dapat meningkatkan kesejahteraan masyarakat di desa. Dalam pembangunan desa, pemerintah desa berkedudukan sebagai subsistem dari penyelenggaraan pemerintahan di Indonesia, sehingga desa memiliki kewenangan, tugas dan kewajiban untuk mengatur dan mengurus kepentingan masyarakatnya sendiri.

Ada 4 (empat) sumber pembiayaan yang dikelola oleh desa yaitu sumber pembiayaan dari pusat; sumber pembiayaan dari daerah baik kabupaten maupun provinsi; sumber pembiayaan yang berasal dari usaha desa dan sumber pembiayaan lainnya. Anggaran yang bersumber dari APBN yang mengalir ke desa terbagi dalam 2 (dua) mekanisme penyaluran yaitu dana transfer ke daerah (on top) secara bertahap yang dikenal dengan Dana Desa dan mekanisme dana transfer melalui APBD kabupaten yang dialokasikan $10 \%$ oleh pemerintah daerah untuk disalurkan ke kas desa secara bertahap yang dikenal dengan alokasi dana desa (ADD). Alokasi dana desa memiliki maksud yaitu sebagai bantuan stimulan atau dana rangsangan untuk mendorong adanya partisipasi swadaya gotong royong masyarakat desa dalam pembiayaan pelaksanaan pembangunan dan pemberdayaan masyarakat di desa.

Guna tercapainya tata kelola pemerintahan desa yang baik, pemerintah desa saat ini dihadapkan pada permasalahan adanya keterbatasan-keterbatasan yang menjadi kelemahan dalam pengelolaan pemerintahannya. Wasistiono dan Tahir (2006:96) menyatakan bahwa unsur kelemahan yang dimiliki oleh pemerintahan desa pada umumnya yaitu : (1) Kualitas sumber daya aparatur yang dimiliki desa pada umumnya masih rendah. (2) Belum sempurnanya kebijakan pengaturan tentang 
organisasi pemerintah desa, sejak dikeluarkan Peraturan Pemerintah Nomor 72 Tahun 2005 tentang desa, masih diperlukan beberapa aturan pelaksana baik sebagai pedoman maupun sebagai operasional. (3) Rendahnya kemampuan perencanaan di tingkat desa, sering berakibat pada kurangnya sinkronisasi antara output (hasil/keluaran) implementasi kebijakan dengan kebutuhan masyarakat yang merupakan input dari kebijakan. (4) Sarana dan prasarana penunjang operasional administrasi pemerintah masih sangat terbatas, selain mengganggu efisiensi dan efektivitas pelaksanaan pekerjaan, juga berpotensi menurunkan motivasi aparat pelaksana, sehingga pada akhirnya menghambat pencapaian tujuan, tugas, dan pekerjaan. Pendapat dari ahli di atas menegaskan bahwa keterbatasan-keterbatasan yang dimiliki oleh desa akan berpengaruh terhadap pengelolaan pemerintahannya, dalam penelitian ini yaitu pengelolaan alokasi dana desa.
Fenomena tersebut diatas telah menjelaskan meskipun dihadapkan pada permasalahan adanya keterbatasan-keterbatasan yang dimiliki oleh desa pada umumnya, Desa Alasmalang telah mampu melaksanakan seluruh program kegiatan alokasi dana desanya tahun 2015 sebagaimana ketentuan yang berlaku sebagaimana hasil pemeriksaan Inspektorat Kabupaten Situbondo. Peneliti tertarik untuk melakukan penelitian secara mendalam fokus kepada proses pengelolaan alokasi dana desa Tahun 2015 di Desa Alasmalang yang telah terlaksana mulai dari tahapan perencanaan, pelaksanaan, dan pertanggungjawabannya. Penelitian ini menjadi penting karena nantinya dapat mengetahui tentang bagaimana peran Kepala Desa, pelaksana kegiatan, seluruh stakeholder, dan keterlibatan masyarakat dengan segala keterbatasan yang dimiliki oleh Pemerintah Desa dapat mengelola alokasi dana desanya dengan baik. 


\section{TINJAUAN PUSTAKA}

\subsection{Pengelolaan}

Kata pengelolaan dapat disamakan dengan manajemen, berarti pula pengaturan atau pengurusan (Arikunto, 1993:31).

Menurut Stoner (dalam Kaho, 1997:228) manajemen dapat dilihat sebagai proses, yakni: proses perencanaan, pengorganisasian, pengarahan dan pengawasan. Maka, pengelolaan dapat diartikan sebagai suatu rangkaian pekerjaan atau usaha yang dilakukan oleh sekelompok orang untuk melakukan serangkaian kerja dalam mencapai tujuan tertentu.

\subsection{Perencanaan}

Menurut Sutarno (2004:109), perencanaan diartikan sebagai perhitungan dan penentuan tentang apa yang dijalankan dalam rangka mencapai tujuan tertentu dimana menyangkut tempat, oleh siapa pelaku itu atau pelaksanaan tata cara mencapai tujuan tersebut.

Pada prinsipnya perencanaan merupakan suatu proses yang tidak mengenal akhirnya dan untuk mencapai hasil yang memuaskan maka harus mempertimbangkan kondisi diwaktu yang akan datang. Pada hakekatnya perencanaan adalah sebuah proses yang penting dan menentukan keberhasilan suatu tindakan (Suharto, 2010:71).

\subsection{Pelaksanaan}

Menurut Rue dan Byars (2006: 6) Organizing is grouping activities, assigning activities an providing the authority necessary to carry out the activities (pengorganisasian merupakan pengelompokan kegiatan-kegiatan penugasan kegiatan-kegiatan penyediaan keperluan, wewenang untuk melaksanakan kegiatannya).

Pelaksanaan atau pengorganisasian juga dapat diartikan sebagai proses membagi kerja ke dalam tugas-tugas yang lebih kecil, membebankan tugastugas itu kepada orang yang sesuai dengan kemampuannya dan mengalokasikan sumber daya serta mengkoordinasikannya dalam rangka efektivitas pencapaian tujuan (Fattah, 2004:71). Jadi setelah melaksanakan perencanaan maka langkah 
selanjutnya adalah pengorganisasian, dalam hal ini harus jelas siapa yang menjalankan dan yang dijalankan, agar semuanya berjalan dengan lancar.

Tahap pelaksanaan program intinya menunjuk pada perubahan proses perencanaan pada tingkat abstraksi yang lebih rendah. Penerapan kebijakan atau pemberian pelayanan merupakan tujuan, sedangkan operasi atau kegiatankegiatan untuk mencapainya adalah alat pencapaian tujuan (Suharto, 2010:79).

\subsection{Pertanggungjawaban}

Menurut Agus (2012:25) bahwa bertanggung jawab merupakan sikap dan perilaku seseorang dalam melakukan tugas dan kewajibannya baik terhadap diri sendiri, masyarakat, lingkungan alam, lingkungan sosial budaya, negara, dan Tuhan. Menurut Hawari (2012:199) tanggung jawab adalah perilaku yang menentukan bagaimana kita bereaksi setiap hari, apakah kita cukup bertanggungjawab untuk memegang komitmen, menggunakan sumberdaya, menjadi toleran dan sabar, menjadi jujur dan adil, membangun keberanian, serta menunjukkan kerja sama.

\subsection{Alokasi Dana Desa}

Menurut Peraturan Pemerintah Nomor 43 Tahun 2014 Pasal 1 Ayat 9 yang dimaksud alokasi dana desa adalah dana perimbangan yang diterima kabupaten/kota dalam anggaran pendapatan dan belanja daerah kabupaten/kota setelah dikurangi dana alokasi khusus. Pasal 96 ayat 2 menyebutkan bahwa besaran Alokasi Dana Desa paling sedikit $10 \%$ (sepuluh perseratus) dari dana perimbangan yang diterima kabupaten/kota dalam Anggaran Pendapatan dan Belanja Daerah Kabupaten/Kota setelah dikurangi Dana Alokasi Khusus.

\subsection{Asas Pengelolaan Alokasi \\ Dana Desa}

Menurut Sahdan,dkk. (2006:23) pengelolaan alokasi dana desa harus menyatu di dalam pengelolaan APBDes, sehingga prinsip pengelolaan alokasi dana desa sama persis dengan pengelolaan APBDesa, 
yang harus mengikuti prinsip-prinsip good governance, yakni:

1. Partisipasif, proses pengelolaan alokasi dana desa mulai perencanaan, pengambilan keputusan sampai dengan pengawasan serta evaluasi harus melibatkan banyak pihak, artinya dalam mengelola alokasi dana desa tidak hanya melibatkan para elit desa saja (pemerintah desa, $\mathrm{BPD}$, pengurus $\mathrm{LPMD} / \mathrm{RT} / \mathrm{RW}$ ataupun tokoh-tokoh masyarakat), tetapi juga harus melibatkan masyarakat lain seperti petani, kaum buruh, perempuan, pemuda dan sebagainya;

2. Transparan, semua pihak dapat mengetahui keseluruhan proses

\section{METODE PENELITIAN}

Jenis penelitian yang digunakan dalam penelitian ini adalah penelitian kualitatif dengan pendekatan studi kasus. Metode studi kasus ini dianggap cocok untuk digunakan dalam penelitian ini karena peneliti nantinya akan mendalami suatu fenomena yang terjadi dalam pengelolaan alokasi dana desa di secara terbuka. Selain itu, diupayakan agar masyarakat desa dapat menerima informasi mengenai tujuan, sasaran, hasil, manfaat, yang diperolehnya dari setiap kegiatan yang menggunakan dana ini;

3. Akuntabel, keseluruhan proses penggunaan alokasi dana desa, mulai dari usulan peruntukannya, pelaksanaan sampai dengan pencapaian hasilnya dapat dipertanggungjawabkan di depan seluruh pihak terutama masyarakat desa;

4. Kesetaraan, semua pihak yang terlibat dalam pengelolaan alokasi dana desa mempunyai hak dan kedudukan yang sama.

Desa Alasmalang. Penelitian ini dilaksanakan di Desa Alasmalang Kecamatan Panarukan Kabupaten Situbondo pada bulan April 2017. Dalam penelitian kualitatif, yang menjadi instrumen atau alat penelitian adalah peneliti itu sendiri.

Data primer pada penelitian ini diperoleh dari informan yang 
mengikuti mekanisme pengelolaan alokasi dana desa di Desa Alasmalang yaitu Kepala Desa Alasmalang, Sekretaris Desa selaku Koordinator, Bendahara Desa, Pelaksana Teknis Kegiatan, Tim Pengelola Kegiatan, BPD dan LPMD. Data sekunder, yakni data yang diperoleh melalui laporanlaporan atau buku-buku atau catatancatatan yang berkaitan erat dengan permasalahan yang diteliti, diantaranya keputusan bupati tentang besaran alokasi dana desa bagi desadesa di Kabupaten Situbondo, APBDesa, RKPDesa, laporan penggunaan dana dan pertanggungjawaban alokasi dana desa Desa Alasmalang, serta Hasil
Pemeriksaan Reguler dari Inspektorat Kabupaten Situbondo tentang Pengelolaan Alokasi Dana Desa.

Informan dalam penelitian pengelolaan alokasi dana Desa tahun 2015 pada Desa Alasmalang ini antara lain: Kepala Desa Alasmalang, Sekretaris Desa, Bendahara Desa, Kadus Tanah Anyar dan Pancor, Ketua dan Sekretaris TPK, Ketua dan Sekretaris BPD, Ketua dan Sekretaris LPM, Ketua HIPPA.

Teknik pengumpulan data dalam penelitian ini dilakukan dengan beberapa metode yaitu: wawancara mendalam, pengamatan, dokumentasi, dan triangulasi data.

\section{HASIL PENELITIAN DAN PEMBAHASAN}

\subsection{Tahapan Perencanaan}

Berdasarkan hasil wawancara dengan Kasun Tanah Anyar dan Ketua BPD Alasmalang, peneliti mengambil suatu kesimpulan bahwa Desa Alasmalang telah melaksanakan proses perencanaan pengelolaan alokasi dana desa melalui musyawarah. Proses perencanaan tersebut diawali melalui mekanisme musyawarah dusun dengan melibatkan perwakilan masyarakat yang ada di RT dan RW secara terbuka, sehingga memberikan kesempatan warganya untuk berpartisipasi aktif terlibat dalam proses perencanaan sebagaimana penjelasan Mahrito selaku Kepela Dusun Tanah Anyar. Keterangan Ketua BPD Desa 
Alasmalang juga telah menegaskan bahwa komitmen dari anggota BPD yang telah melaksanakan tugas dan fungsinya sebagai representasi masyarakat Desa Alasmalang telah berperan aktif dalam penyelenggaraan musyawarah dusun agar masyarakat bisa menyampaikan usulan programnya. Cara demikian secara tidak langsung telah mendorong terciptanya suasana demokrasi di desa dengan memberikan ruang kepada warga untuk menyampaikan pendapatnya. Komitmen tersebut memberikan kontribusi yang positif terhadap keberhasilan proses perencanaan penggunaan anggaran alokasi dana desa sebagaimana harapan warga. Hasil analisis yang telah dilakukan oleh peneliti telah sesuai dengan pendapat Sahdan, dkk. (2006:7) bahwa salah satu manfaat dari alokasi dana desa yaitu dapat mendorong terciptanya demokrasi di desa.

Keterlibatan warga dalam proses musyawarah dusun ini merupakan bentuk pelaksanaan prinsip-prinsip tata kelola pemerintahan yang baik (good governance) yaitu prinsip partisipatif.

Berdasarkan penjelasan Kepala Desa Alasmalang, peneliti berkesimpulan bahwa Kepala Desa Alasmalang memiliki pandangan keterlibatan masyarakat sangat mutlak dibutuhkan dalam proses perencanaan untuk mengambil suatu kebijakan alokasi dana desa. Masyarakat tidak hanya dianggap sebagai obyek tetapi juga sebagai subyek dalam pelaksanaan kebijakan program melalui alokasi dana desa. Menurut peneliti, cara pandang Kepala Desa Alasmalang tersebut sangat mendukung terhadap keberhasilan pengelolaan alokasi dana desa. Hal tersebut menjadi nilai lebih bagi seorang kepala desa yang menginginkan program kegiatan alokasi dana desanya dapat terlaksana dengan baik berdasarkan atas keinginan dan kebutuhan masyarakatnya. Model implementasi kebijakan program kegiatan alokasi dana desa di Desa Alasmalang yang didasarkan pada proses perencaaan, dengan melibatkan partisipasi masyarakat mulai tingkat dusun ini cenderung pada model implementasi 
kebijakan publik dengan pendekatan bottom up.

Berdasarkan penjelasan dari beberapa informan di atas, peneliti dapat menyimpulkan bahwa perencanaan pengelolaan alokasi dana desa tahun 2015 di Desa Alasmalang berhasil dengan baik. Proses perencanaan dilaksanakan secara terstruktur mulai dari musyawarah dusun, musyawarah desa, dan musyawarah perencanaan pembangunan desa, namun masih belum tertib mengenai waktu pelaksanannya sebagaimana peraturan yang berlaku. Program kegiatan yang telah disepakati menjadi skala prioritas pembangunan di Desa Alasmalang diarahkan pada urusan yang berkenaan dengan pengentasan kemiskinan, peningkatan kualitas kesehatan, dan peningkatan ekonomi masyarakat. Seluruh stakeholder dan masyarakat terlibat secara langsung dan terbuka dalam proses perencanaan, sehingga kualitas perencanaan pengelolaan alokasi dana desa pada Desa Alasmalang menjadi baik karena sesuai dengan kebutuhan masyarakatnya. Kualitas perencanaan program kegiatan yang baik menjadi modal awal yang positif terhadap keberhasilan pengelolaan alokasi dana desa pada Desa Alasmalang.

Hasil analisa yang peneliti lakukan sesuai dengan pendapat dari Suharto (2010:71) bahwa keberhasilan dalam suatu perencanaan akan memberikan arah terhadap keberhasilan dalam suatu kegiatan. Pada hakekatnya perencanaan adalah sebuah proses yang penting dan menentukan keberhasilan suatu tindakan. Dengan kata lain, kunci keberhasilan dalam suatu pengelolaan atau manajemen tergantung pada proses perencanaannya.

\subsection{Tahapan Pelaksanaan}

Berdasarkan penjelasan dari Kepala Desa, Sekretaris Desa dan Ketua BPD Alasmalang, peneliti berkesimpulan bahwa tahapan pelaksanaan alokasi dana desa pada Desa Alasmalang dimulai dengan penunjukan personil sebagai bendahara desa, dan tim pengelola kegiatan secara selektif dan baik. Dalam penunjukan tersebut, Kepala 
Desa Alasmalang menggunakan 2 (dua) pendekatan yaitu top down dan bottom up. Ketika akan menunjuk bendahara desa, kepala desa secara langsung memilih perangkat desanya tanpa meminta saran dari pihak manapun. Hal tersebut dilakukan karena Kepala Desa Alasmalang mengetahui secara jelas kemampuan dan kredibilitas dari perangkat desanya, sehingga akan mudah menempatkan siapa yang akan menjadi bendahara desa. Lain halnya ketika akan menunjuk tim pelaksana kegiatan, Kepala Desa Alasmalang meminta saran masukan dari Ketua BPD. Hal tersebut dilakukan agar nantinya orang-orang yang menjadi anggota tim pelaksana kegiatan benar-benar merupakan orang yang amanah, memiliki kemampuan melaksanakan pengadaan barang/jasa dan pengalaman dibidang bangunan atau kontruksi sehingga dapat melaksanakan tugasnya dengan baik.

Masyarakat Desa Alasmalang menilai tim pengelola kegiatan alokasi dana desa tahun 2015 telah melaksanakan tugasnya dengan baik. Seluruh program kegiatan yang telah direncanakan melalui alokasi dana desa telah selesai dilaksanakan dengan tuntas. Tim pengelola kegiatan secara transparan memberikan informasi tentang pelaksanaan kegiatannya. Hal itu dapat dilihat melalui papan informasi seluruh kegaiatan yang didanai melalui anggaran alokasi dana desa yang dipampang di depan kantor desa, dan juga yang dipasang di tempat kegiatan dilaksanakan, mengenai nama kegiatan, volume, besaran anggaran, dan waktu pelaksanaannya. Hal tersebut sesuai ungkapan dari Ketua LPM Desa Alasmalang.

Berdasarkan penjelasan Ketua TPK, peneliti berkesimpulan bahwa tim pengelola kegiatan telah berhasil melaksanakan program kegiatan secara transparan. Bentuk transparansi tersebut melalui penempatan papan informasi kegiatan di setiap lokasi kegiatan. Dengan tersedianya papan informasi kegiatan itu, tim pengelola kegiatan mempunyai tujuan agar masyarakat bisa berpartisipasi langsung mengawasi dan mengontrol 
pelaksanaan kegiatan tersebut. Pengawasan yang dilakukan langsung oleh masyarakat akan memberikan motivasi kepada tim pengelola kegiatan untuk dapat mengerjakan kegiatan tersebut dengan sebaik mungkin sehingga kualitas hasil pekerjaannya menjadi baik sebagaimana keinginan masyarakat.

Berdasarkan penjelasan Sekretaris BPD, Kasun Tanah Anyar dan Sekretaris TPK, peneliti berkesimpulan bahwa masyarakat Desa Alasmalang merasa puas atas hasil pekerjaan yang telah dilaksanakan oleh tim pengelola kegiatan alokasi dana desa. Masyarakat dapat memanfaatkan hasil pekerjaan itu untuk memudahkan aktivitas mereka. Kualitas hasil pekerjaan yang baik tidak lepas dari komitmen dari tim pengelola kegiatan itu sendiri. Motivasi bekerja dengan baik untuk menghasilkan sesuatu yang baik dan bisa bermanfaat bagi masyarakat yang dihubungkan dengan nilai ibadah menjadi kunci keberhasilan tugas dari tim pengelola kegiatan. Sehingga secara akuntabilitas, kualitas hasil pekerjaannya dapat dipertanggungjawabkan kepada masyarakat Desa Alasmalang. Masyarakat dapat membuktikan secara langsung kualitas dan manfaat dari hasil pekerjaan alokasi dana desa tersebut dengan baik. Namun ditemukan pada bangunannya belum terpasang prasasti atau tanda pengenal sumber dana kegiatan tersebut.

Berdasarkan atas penegasan Sekretaris LPM dan Kepala Desa Alasmalang, peneliti berkesimpulan bahwa tingkat partisipasi masyarakat dalam pelaksanaan program kegiatan alokasi dana desa pada Desa Alasmalang sangat tinggi. Hal tersebut dibuktikan dengan keterlibatan masyarakat dalam pelaksanaan program alokasi dana desa dengan suka rela. Mereka memberikan bantuan berupa tenaga dan materi turut serta terlibat dalam pelaksanaan pembangunan fisik yang didanai dari alokasi dana desa, seperti pembangunan pos ronda. Hal yang menarik dari hasil wawancara peneliti dengan informan, ada nilai budaya kegotong royongan atau keguyuban masyarakat Desa 
Alasmalang yang sampai saat ini terpelihara dengan baik. Budaya gotong royong tersebut menjadi salah satu hal pendukung atas keberhasilan pelaksanaan program alokasi dana desa. Karena dengan adanya dukungan masyarakat akan menciptakan kondusifitas lingkungan yang secara tidak langsung berkontribusi terhadap keberhasilan dalam pelaksanaan program alokasi dana desa pada Desa Alasmalang.

Hasil analisis yang dilakukan oleh peneliti sesuai dengan pendapat Soemantri (2011: 157) bahwa salah satu tujuan dari alokasi dana desa yaitu mendorong peningkatan keswadayaan dan gotong royong masyarakat. Sehingga alokasi dana desa bisa berfungsi sebagai stimulan dalam pembangunan desa yang dapat merangsang munculnya swadaya dan gotong royong masyarakat desa.

\subsection{Tahapan}

\section{Pertanggungjawaban}

Merujuk pada pernyataan dari Kepala Desa dan Sekretaris Desa Alasmalang, peneliti dapat menyimpulkan bahwa penyelesaian laporan pertanggungjawaban atas pengelolaan alokasi dana desa tahun 2015 pada Desa Alasmalang sudah selesai tepat waktu. Keberhasilan penyusunan laporan pertanggungjawaban tersebut didukung oleh ketersediaan dokumen dan bukti pendukung penggunaan alokasi dana desa sesuai dengan kondisi riil pelaksanaannya yang telah dipersiapkan oleh tim pengelola kegiatan. Bendahara desa dengan kemampuan dan pengetahuannya dalam penatausahaan keuangan alokasi dana desa, mampu berkoordinasi dengan baik dengan tim pengelola kegiatan. Selain itu juga, ada komitmen yang sama untuk mewujudkan pengelolaan alokasi dana desa tahun 2015 dengan baik, sesuai dengan tugasnya masingmasing. Hal yang menarik dari keterangan di atas, bahwa keberhasilan dalam penyusunan laporan pertanggungjawaban tidak hanya bergantung pada seorang bendahara desa saja, melainkan pada semua pelaksana pengelolaan alokasi dana desa. 
Pertanggungjawaban

penggunaan alokasi dana desa tahun 2015 Desa Alasmalang telah dilakukan pemeriksaan oleh Inspektorat Kabupaten Situbondo dengan hasil yang menunjukkan bahwa Desa Alasmalang mampu menyajikan laporan pertanggungjawaban dengan baik. Hal itu menjadi bukti bahwa Desa Alasmalang mampu menyajikan laporan pertanggungjawaban secara akuntabilitas hukum dapat diterima oleh pemeriksa dari Inspektorat Kabupaten Situbondo. Karena tidak ditemukan adanya kegiatan penggunaan alokasi dana desa yang tidak bisa atau belum bisa dipertanggungjawabkan. Seluruh kegiatan telah selesai dikerjakan dengan dilengkapi bukti pendukung yang dapat diterima dan bisa dipertanggungjawabkan secara hukum kebenarannya.

Berdasarkan pernyataan Kepala Desa dan Ketua BPD Alasmalang serta beberapa analisis yang peneliti lakukan sebelumnya, maka peneliti berkesimpulan bahwa pertanggungjawaban atas alokasi dana desa tahun 2015 pada Desa
Alasmalang tahun 2015 sudah terlaksana dengan baik. Keberhasilan tersebut dikarenakan telah mampu menyelesaikan laporan pertanggungjawaban tepat waktu, serta mampu menyajikan dokumen dan bukti pendukung penggunaan anggaran alokasi dana desa yang dapat dipertanggungjawabakan secara hukum. Karena pengelolaan alokasi dana desa merupakan satu kesatuan proses yang saling berkaitan satu dengan lainnya. Perencanaan yang baik berarti merencanakan suatu keberhasilan dalam pelaksanaan, dan pelaksanaan yang baik berarti merancang keberhasilan dalam pertanggungjawabannya (akuntabel) sebagai perwujudan dari salah satu prinsip-prinsip tata kelola pemerintahan yang baik (good governance).

Hasil analisis yang telah dilakukan oleh peneliti telah sesuai dengan pernyataan Sahdan, dkk. (2006:23) keseluruhan proses penggunaan alokasi dana desa, mulai dari usulan peruntukannya, pelaksanaan sampai dengan pencapaian hasilnya dapat 
dipertanggungjawabkan di depan seluruh pihak terutama masyarakat desa.

Hasil pengamatan peneliti, secara laporan pertanggungjawaban sudah baik akan tetapi dalam pengarsipan dokumen pertanggungjawaban masih kurang tertib. Dokumen laporan tidak

\section{KESIMPULAN DAN SARAN}

\subsection{Kesimpulan}

Berdasarkan pembahasan dan analisis hasil penelitian, maka diambil kesimpulan sebagai berikut:

1. Pengelolaan alokasi dana desa tahun 2015 pada Desa Alasmalang sudah terlaksana dengan baik, transparan, partisipatif, serta akuntabel.

2. Perencanaan pengelolaan alokasi dana desa tahun 2015 pada Desa Alasmalang berhasil dengan baik. Proses perencanaan dilaksanakan secara terstruktur mulai dari musyawarah dusun, musyawarah desa, dan musyawarah perencanaan pembangunan desa. Seluruh stakeholder dan masyarakat berpastisipasi secara langsung diletakkan pada tempat dengan tanda pengenal khusus, sehingga kesulitan ketika membutuhkan dokumen tersebut. Maka, menurut peneliti seharusnya ada tempat khusus dalam pengarsipan dokumen laporan pertanggungjawaban untuk mempermudah ketika dibutuhkan sewaktu-waktu.

dan terbuka dalam proses perencanaan, sehingga kualitas perencanaan pengelolaan alokasi dana desa pada Desa Alasmalang menjadi baik karena sesuai dengan kebutuhan masyarakatnya. Kualitas perencanaannya sudah baik, akan tetapi belum tertib waktu pelaksanaannya sebagaimana peraturan yang berlaku.

3. Pelaksanaan program kegiatan alokasi dana desa tahun 2015 pada Desa Alasmalang berhasil dengan baik. Diawali dengan penunjukan bendahara desa dan tim pengelola kegiatan yang memiliki kemampuan dan pengalaman di bidang kontruksi dan pengadaan barang/jasa oleh 
kepala desa. Seluruh program kegiatan alokasi dana desa telah terlaksana dengan baik. Tim pengelola kegiatan telah memberikan ruang keterlibatan masyarakat untuk berpartisipasi dalam pelaksanaan program, sehingga hasil yang dicapai sesuai dengan harapan masyarakat. Nilai budaya kegotong royongan atau keguyuban masyarakat Desa Alasmalang yang sampai saat ini terpelihara dengan baik, menjadi salah satu hal pendukung atas keberhasilan pelaksanaan program alokasi dana desa. Secara keseluruhan kualitas hasil pembangunan fisik sudah baik, akan tetapi pada bangunannya belum diberikan tanda atau prasasti sebagai informasi bahwa bangunan tersebut bersumber dari anggaran alokasi dana desa tahun 2015.

4. Pertanggungjawaban atas alokasi dana desa tahun 2015 pada Desa Alasmalang tahun 2015 sudah terlaksana dengan baik. Keberhasilan tersebut dikarenakan telah mampu menyelesaikan laporan pertanggungjawaban tepat waktu, serta mampu menyajikan dokumen dan bukti pendukung penggunaan anggaran alokasi dana desa yang dapat dipertanggungjawabakan secara hukum. Koordinasi dan kerjasama bendahara desa dengan tim pengelola kegiatan yang baik, pemahaman atas tugas dan fungsi masing-masing, serta komitmen bersama agar pengelolaan alokasi dana desa dapat berjalan dengan baik memberikan kontribusi yang positif atas kualitas pelaporan pertanggungjawaban penggunaan alokasi dana desa pada Desa Alasmalang. Secara dokumen laporan pertanggungjawaban sudah baik, akan tetapi dokumen tersebut belum disimpan pada tempat yang khusus dan belum diberi tanda pengenal untuk pengarsipannya.

\subsection{Saran}

Berdasarkan beberapa kesimpulan atas hasil penelitian di 
atas, peneliti dapat memberikan saran sebagai berikut :

1. Proses perencanaan dalam pengelolaan alokasi dana desa harus dilaksanakan sesuai waktu yang telah ditetapkan sebagaimana ketentuan yang berlaku, agar jadual penetapan produk perencanaannya seperti RKPDesa dan APBDesa tepat waktu.

2. Hasil pelaksanaan pekerjaan yang telah selesai agar diberikan tanda atau prasasti bahwa pekerjaan bangunan fisik tersebut bisa diketahui bersumber dari alokasi dana desa tahun 2015.

3. Dokumen laporan pertanggungjawaban agar disimpan pada tempat yang lebih aman dan tertib serta diarsip dengan tanda pengenal yang mudah diketahui sehingga ketika dibutuhkan bisa cepat didapat.

4. Kepala Desa Alasmalang agar melaksanakan pertemuan dengan seluruh pihak yang terlibat dalam pengelolaan alokasi dana desa untuk mengevaluasi terhadap proses pengelolaannya mulai dari perencanaan, pelaksanaan, dan pertanggungjawabannya. Hal ini bertujuan untuk mendapatkan saran dan masukan agar pengelolaan alokasi dana desa ke depannya menjadi lebih baik lagi.

\section{DAFTAR PUSTAKA}

A. Hamid S. Attamimi. 2009. Pengertian Keuangan Negara Menurut UUD 1945, Pasal 23. Jakarta: PT. Rajawali Pers.

Arikunto, Suharsimi. 1993. Manajemen Penelitian.Jakarta: PT. Raja Grafindo Perkasa.

Bungin, Burhan, H.M. 2011. Penelitian Kualitatif, Komunikasi, Ekonomi, Kebijakan Publik, dan Ilmu Sosial Lainnya. Edisi Kedua. Jakarta: Kencana.

Byars, Llloyd L dan Rue, Leslie W. 2006. Human Resource Management. 8th Edition. MCGraw-Hill: Irwin

Fattah, Nanang. 2004. Landasan Manajemen. Bandung: Rosda.

Creswell, John W. 2010. Research Design Pendekatan Kualitatif, Kuantitatif, dan Mixed Edisi Ke-3. Yogyakarta: Pustaka Pelajar. 
Kaho, Josef Riwu. 1997. Prospek Otonomi Daerah di Negara Republik Indonesia. Jakarta: Raja Grafindo Perkasa.

Moleong, J Lexy. 2007. Metode Penelitian Kualitatif. Bandung : Remaja RosdaKarya.

Muhi, A. H. 2011. Optimalisasi Pelaksanaan Fungsi Pengawasan Dewan Perwakilan Rakyat Daerah Dalam Penyelenggaraan Pemerintahan - Paper. Sumedang: Institut Pemerintahan Dalam Negeri (IPDN).

Peraturan Pemerintah Nomor 43 Tahun 2014 tentang Peraturan Pelaksanaan Undang-Undang Nomor 6 Tahun 2014 tentang Desa.

Peraturan Bupati Situbondo Nomor 3 Tahun 2015 tentang Pedoman Penyaluran Alokasi Dana Desa dan Bagian dari Hasil Pajak Daerah dan Retribusi Daerah di Kabupaten Situbondo.

Peraturan Bupati Situbondo Nomor 42 Tahun 2015 tentang Pedoman Pengelolaan Keuangan Desa.

Rasul, Syahrudin, 2003. Pengintegrasian Sistem Akuntabilitas Kinerja dan Anggaran dalam Perspektif UU NO. $\quad 17 / 2003 \quad$ Tentang Keuangan Negara. Jakarta: PNRI

Sahdan, G., Iswari, P. dan Zamroni, S. 2006. ADD untuk Kesejahteraan Rakyat Desa. Yogyakarta: Forum Pengembangan Pembaharuan Desa.
Siagian, Sondang P. 2004. Teori Motivasi dan Aplikasinya. Jakarta: Rineka Cipta.

Soemantri, Trisantono Bambang. 2011. Pedoman

Penyelenggaraan

Pemerintahan Desa. Bandung: Fokusmedia.

Sugiyono. 2009. Metode Penelitian Kuantitatif dan Kualitatif. Bandung: $\quad$ CV. Alfabeta.

Suharto, Edi. 2010. Membangun Masyarakat Memberdayakan Rakyat. Bandung: PT Refika Aditama.

Sumodiningrat, Gunawan dan Nugroho, Riant. 2005. Membangun Indonesia Emas. Jakarta: PT Elex Media Komputindo.

Suradinata, 1996. Manajemen Sumber Daya Manusia-Suatu Tinjauan Wawasan Masa Depan. Bandung: Ramadan.

Suradinata. 1998. Manajemen Pemerintahan dan Otonomi Daerah. Bandung: Ramadan.

Sutarno, NS. 2004. Manajemen Perpustakaan. Jakarta: Sagung Seto.

Thoha, Miftah. 2008. Ilmu Administrasi Publik Kontemporer. Jakarta: Prenada Media Grup.

Undang-Undang Nomor 6 Tahun 2014 tentang Desa.

Wasistiono dan Tahir. 2007. Prospek Pengembangan Desa. Bandung: Fokusmedia.

Yuwono, Teguh dan Warsito. 2001. Manajemen Otonomi Daerah. Semarang: CLOGAPPS. 